Nosko 5., Ahaiev I.

\title{
CONTROL OF VORTEX STRUCTURES OF ABNORMALLY VISCOUS FLUIDS IN THE CHANNELS OF THE EXTRUSION DIE
}

Об’єктом дослідження є вихрові структури, що виникають при перебігу аномально-в'язких середовищ, в каналах формувального обладнання. Одним з найбільш проблемних місць є недостатня вивченість процесів зародження і розвитку циркуляційних течій. Це пов'язано з тим, що гідродинамічні механізми цих процесів не зовсім зрозумілі. Причиною щього є відсутність точних аналітичних рішень, що дозволяють описати модель процесу $і$ вибрати метод гідродинамічного управління вихровими структурами $і$ на його основі удосконалити формуюче обладнання.

В ході досліджень встановлено, що найбільш дієвим способом управління гідродинамічними характеристиками потоку в області різкого звуження каналу є підведення додаткової витрати рідини в радіальному напрямку по відношенню до основного потоку. Розроблено конструкцію формуючої головки, яка дозволяє реалізувати режим змішування компонентів з поліпшеними технологічними та енергетичними показниками. Це пов'язано з тим, що запропонований метод управління вихровими структурами має ряд відмінних рис, зокрема екструдованна середа проходила через канали головки у вигляді раптового звуження, а потім по ходу течії, конусного розширення. Технологічний компонент, який підлягає змішанню, подається радіально в область вихрових структур із зоною зниженого тиску. Завдяки цьому забезпечується можливість зриву вихрових структур, турбулізація течї $і$ інтенсивне змішання основного $і$ додаткового потоків. У порівнянні з аналогічним відомим обладнанням в каналах головки не передбачено розташування змішувальних пристроїв і стаціонарних турбулізаторів, що знижує енерговитрати на прочес екструзї. Крім того, надається можливість для подачі технологічного компонента в базовий потік використовувати насос меншої потужності.

Розроблений пристрій для введення технологічних компонентів в екструдованний матеріал оформлено патентом України № 201503942.

Ключові слова: раптове звуження каналу, вихрові структури, підведення витрат в радіальному напрямку.

\section{Introduction}

The inclusion of technological components into the extruded material is widely used in the production of polymer compositions, co-extrusion of food products, petrochemical industry, as well as in other industries that use extrusion.

The determining factor of the technology of input and mixing of components is the processes occurring in the extrusion die. To implement these processes in practice, extrusion dies of various types are used, characterized by a multitude of working channel configurations [1].

Symmetrically tapering and expanding channels are common elements of extrusion dies. At the same time, the geometric simplicity of the channels does not lead to symmetrical flows, moreover, the flow of the liquid is characterized by such effects as secondary circulation structures and compression of the flow in the narrow part of the channel.

At the same time, the implementation of mixing technologies is significantly limited due to the lack of efficient and simultaneously simple in terms of design execution of equipment that mixes components in the liquid phase with the possibility of operative process control.

Different methods of extrusion mixing of technological components on real objects are not effective enough, since they have a narrow specialization and do not take into account the hydrodynamic features of the interaction of the extruded stream with the introduced formulation component. In addition, the development of equipment often does not take into account the effect of the design parameters of the channels of the extrusion dies on the amount of useful power at a given extruder capacity. In most cases of design, the task of optimizing these technological processes is to eliminate stagnant zones in the channels of the forming equipment.

In this regard, relevant studies are devoted to the search for ways to improve the technological processes of mixing components in extruded material. When developing appropriate technological solutions, it is necessary to take into account the peculiarities of the rheological and hydrodynamic behavior of mixing media in the equipment channels.

\section{The object of research and its technological audit}

The object of research is the vortex structures arising during the flow of anomalously viscous media in the channels of the forming equipment. One of the most problematic places is insufficient knowledge of the processes of origin and development of circulation flows. This is due to the fact that the hydrodynamic mechanisms of these processes are not completely understood. The reason for 
this is the lack of precise analytical solutions that allow describing the process model and choose the method of hydrodynamic control of vortex structures and on its basis to improve forming equipment.

To identify the specifics of management methods, a technological audit was conducted to determine the hydrodynamic conditions for the detachment of vortex structures when additional flow is applied to the area of sudden narrowing of the channel.

The studies were carried out on an experimental bench of a closed type, the channels of which were made of Plexiglas (polymethylmethocrystal), which possesses the necessary optical properties. This made it possible to study the kinematic characteristics of the flow by optical visualization. The flow rate of the fluid was steplessly controlled by the pump by changing the number of revolutions of the DC motor. This made it possible to carry out investigations in a wide range of Reynolds numbers (10-10000) with diverse media, in terms of their physicochemical properties. The flow rate was measured by a volumetric flowmeter.

Observation of the object during the experiment allows to state the following. The method of controlling vortex structures is useful for turbulence of flow with a certain ratio of the main and secondary flows. In this case, the most important should be considered the need to control the effective viscosity of the medium, the geometric parameters of the sudden narrowing of the channel and the Reynolds number. This will allow in practical conditions to increase the efficiency of the process of mixing components and reduce the energy costs associated with extrusion technology.

\section{The aim and objectives of research}

The aim of research is development of hydrodynamic methods for controlling vortex structures in channels of forming equipment, leading to turbulent mixing of flows.

To achieve this aim, it is necessary to solve the following tasks:

1. To determine the influence of the rheological properties of the liquid on the processes of the vortex formation of the flow in the region of sudden narrowing of the channel.

2. To set the value of the additional flow introduced in the radial direction relative to the main flow at which the vortex structures are disrupted.

3. To develop a constructive solution for the extrusion die, which provides a rational mode of mixing technological components.

\section{Research of existing solutions of the problem}

The following studies should be noted of the modern studies analyzing the unstable flow of non-Newtonian media with the formation of stagnant zones in the angular regions of the forming head.

In [2-6], an isothermal flow of a viscoelastic fluid in channels with a sharp symmetric constriction is investigated. The authors, using Maxwell's relaxation model by the control volume method, establish that there exists a dependence of the dimensionless region of the circulation flow on the Deborah number. It is also shown that the flow scheme with a smooth transition from a wide part of the channel to a narrow one leads to a decrease in the dimensions of the region of the circulation flow. However, it should be noted that in these studies the influence of the temperature of the medium on the development processes of circulation flows is not presented. This means that it is not determined how the processes of vortex formation in the region of sudden narrowing of the channel undergo a change in temperature. From a practical point of view, this can cause difficulties in calculating the hydrodynamic parameters of the forming equipment.

To eliminate this problem, studies of an axisymmetric non-isothermal steady-state and non-stationary flow with a narrowing factor of $8: 1$ are performed in [6-9]. The dynamics of the behavior of the circulation zone and its interaction with the angular flow are shown for different Weissenberg numbers. It is established that when the angular circulation flow is absorbed near the sharp edge of the channel, stress and pressure peaks appear. Despite the practical significance of these results, the problems of eliminating vortex structures are not considered. Obviously, this is due to the complexity of numerical modeling of these processes using the method of control objects.

The expediency of using methods of controlling the process of the onset of the nonlinear effect of loss of flux symmetry is given in [9-13]. A comparison of the flow line contours is shown for flow in the region of sharp channel narrowing for Newtonian, pseudoplastic and dilatant liquids, respectively. Investigations establish the values of Reynolds numbers for each of the model fluids, under which there is a transition from a symmetrical flow to an asymmetric one. However, it should be noted that the introduction of additional elements (blocks) on the walls or the channel axis, in order to eliminate the asymmetry of the flow, has not found practical application. This is due to the fact that the installation of stationary elements in the flow of non-Newtonian media leads to an increase in pressure losses along the length of the channel.

In [14], analytical and experimental studies of unstabilized flow are performed with a radial supply of additional liquid flow to the local resistance region. It is shown that changes in the conditions of fluid entry into a narrow part of the channel affect the flow structure and pressure redistribution along the length of the hydrodynamic initial section. However, the hydrodynamic problems associated with the disruption of vortex structures in the region of sudden narrowing of the channel aren't adequately considered.

Thus, there is reason to assert that vortex stagnant zones are a negative phenomenon for extrusion processes. Circulation flows lead to stress peaks, pulsations of pressure in the flow, disruption of heat and mass transfer processes, and as a consequence, to deterioration in the quality of the obtained products. In the above works, let's consider the possibilities of controlling vortex structures by smoothing (profiling) the input section of the channel or by placing stationary stabilizers in the flow. The first version of control requires additional calculations to determine the shape of the profile for each nomenclature of the processed material. This complicates engineering solutions for designing equipment. In another embodiment, additional pressure losses occur in the channels of the extrusion dies.

In this regard, there is reason to believe that an inadequate study of the hydrodynamic problems of controlling 
the circulation flows of abnormally viscous media in the region of sudden narrowing of the channel predetermines the need for research in this direction.

\section{Methods of research}

5.1. The materials and equipment used in the experiment. The studies were carried out using modular liquids of various concentrations - aqueous solutions of the sodium salt of carboxymethylcellulose (Na CMC) of grade 70/300 (TU 2231-037-26289127) and polyvinyl alcohol (PVA) of grade $7 / 2$ (GOST 10779-89).

Rheological studies of aqueous solutions of polymers were performed on the Rheotest-2 measuring complex with coaxial cylinders (production in GDR).

In order to study the kinematic characteristics of the flow by the method of optical visualization, the channels of the experimental stand were made of Plexiglas (polymethylmethocrystal), which possesses the necessary optical properties.

5.2. Method for determining the rheological properties of model fluids and kinematic flow characteristics. The effect of the concentration of aqueous solutions of polymers on the rheological parameters was estimated from the measurement results with increasing and decreasing shear rate $\left(\gamma_{0}, \mathrm{~s}^{-1}\right)$. Determination of rheological properties of model liquids was carried out on samples of $\mathrm{CMC}$ and PVA at solution concentrations from $2 \%$ to $10 \%$ (dry matter). The temperature range was 20, 40, $60,80,100{ }^{\circ} \mathrm{C}$ for gradients of the steady-state shear rate of $1.5-1310 \mathrm{~s}^{-1}$.

The main indicators of rheological properties, which were determined in the experiment, were chosen:

- effective viscosity $(\mu)$;

- flow index $(n)$;

- consistency constant $(K)$.

The determination of the systematic error of the viscometer was carried out according to the following procedure: viscosimetric measurements of a reference liquid (technical glycerin), the viscosity of which is known and independent of the shear rate.

Determination of the viscosity of model media was carried out according to the following procedure: after holding a portion of the liquid in the working elements of the viscometer (cylinder-cylinder) for 20 minutes and stabilizing the temperature in the interval of $0.5^{\circ} \mathrm{C}$. Further, measurements were made in the regime of uniform increase and decrease of the shear rate. The obtained measurement results were corrected with the help of the correction factors found in the study of the reference liquid for the corresponding values of the shear rate.

The kinematic characteristics of the flow in the region of sudden narrowing were determined by the following method: a visualization method was used, which involved photographing the label particles introduced into the stream and illuminated by the light source. As visualizing particles, an aluminum powder was used, previously defatted and divided into fractions in hydraulic size. This method provides the required accuracy of measurements (about 12-15\%), has a wide informativeness and universality [15].

\section{Research results}

As shown by the experimental data, the rheological model of the flow of the investigated media can be characterized by the Oswald-de Ville power equation:

$$
\tau=K \gamma^{n}
$$

where $\tau$ - shear stress, $\mathrm{N} / \mathrm{m}^{2} ; \gamma$ - shear rate, $\mathrm{s}^{-1} ; K$ - consistency constant, MPa.s; $n$ - flow index.

It should be noted that in terms of the slope of the flow curve, in the range of three decimal orders of change in the shear rate (in logarithmic coordinates), the flow index $n$ is determined, and $\lg K$ is the segment formed by the intersection of the flow curve with the axis $\lg \tau$.

Experimentally obtained points, as well as rheological curves approximating them, of the investigated concentrations of model media with increasing, and correspondingly decreasing, shear rate are shown in Fig. 1.

It should be noted that the investigated solutions behave as pseudo-plastic structures which viscosity decreases with increasing shear rate (Fig. 1, curves 1, 2, 3).

As can be seen from Fig. 1, the flow curves with a smooth increase in the shear rate (upper curves) and a decrease in the shear rate (lower curves) for a low CMC concentration practically coincide (curves 1).

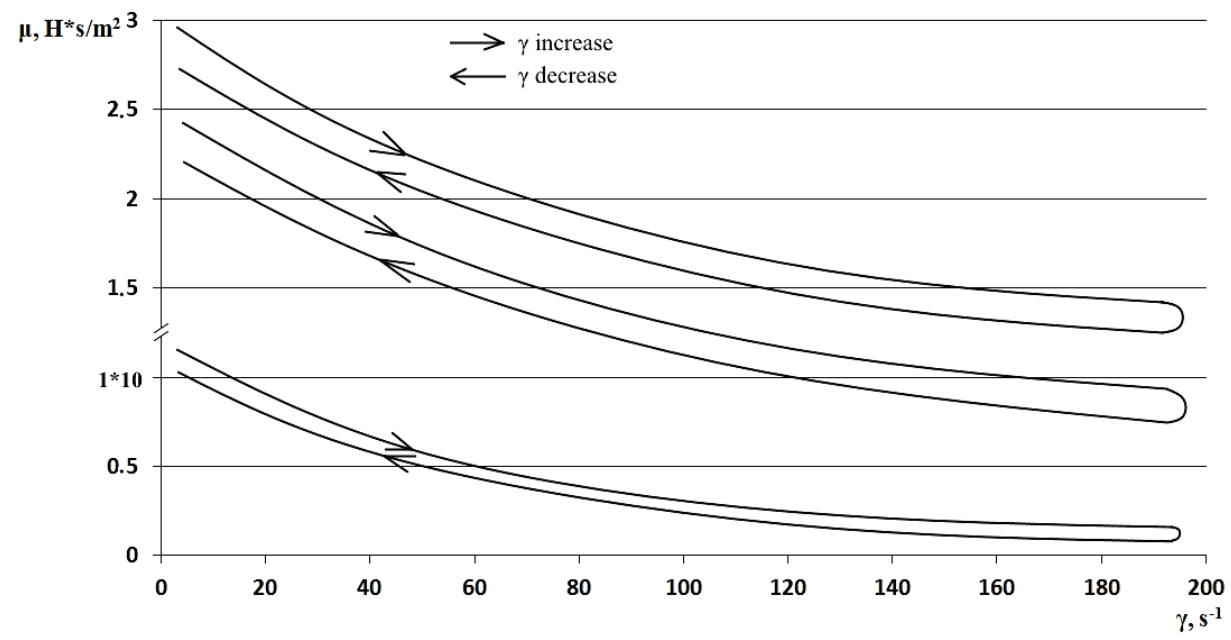

Fig. 1. Dependence of the viscosity CMC and PVA solutions on the shear rate:

1 - concentration of $3 \%$ СMС; 2 - concentration of $8 \%$ СМС; 3 - concentration of $10 \%$ PVA 
With increasing concentration of CMC and PVA solutions, the flow curves (curves 2, 3) form hysteresis loops, that is, the medium exhibits the properties of thixotropy. There is a destruction of the structure of the medium during deformation with a constant shear rate, which leads to a decrease in the effective viscosity.

It should be noted that according to the activation theory of flow [16], the quantitative characteristic of the thixotropy phenomenon can be the area of the hysteresis loop formed by the flow curves.

The results of the dependence of the effective viscosity of solutions of CMC and PVA on temperature are shown in Fig. 2.

It is necessary to pay attention to the fact that in the temperature range $20-100{ }^{\circ} \mathrm{C}$ the effective viscosity of the investigated media (Fig. 2, curves 1, 2, 3) decreases according to the dependence close to exponential.

The obtained results on changes in the shear stress $\tau$ in a wide range of shear rates $\gamma$, characteristic for extrusion processes, can contribute to the selection and calculation of the technological parameters of the forming equipment. In particular, to calculate the shear rate of the medium in the cylindrical part of the extrusion die and the pressure difference $n P$ expended on the flow of material under isothermal conditions [17]:

$$
\gamma=\frac{(3 n+1) Q}{\pi n r^{3}}
$$

where $Q$ - volume flow; $r$ - radius of the channel;

$$
n P=\frac{2 \tau L}{r}=\frac{2 \mu \cdot \gamma L}{r}
$$

where $L$ - length of the channel.

The results of investigations of the kinematic characteristics of the flow in the region of sudden narrowing of the channel are shown in Fig. 3.

It should be noted that in the course of the $3 \%$ aqueous solution of $\mathrm{CMC}$ with the value of the generalized Reynolds number $R e<90$, no pronounced vortex formation was observed in the region of sudden constriction (contraction coefficient $K_{0}=S_{1} / S_{2}=3$ ). The main vortex $A$ is formed at $R e>120$, and the clearly expressed axis of rotation of the vortex appears at $R e>320$ (Fig. 3). Further, as the Reynolds number increases $(R e>1300)$, a decrease in the intensity of the vortex structure, a decrease in its size, and some displacement of the axis of rotation toward the side wall of the channel are observed.

The results of the research show that when $R e$ reaches 1560-1600, the main vortex $A$ disconnects, some volume of liquid separates from the vortex and moves along the side wall in the direction opposite to the main stream. The part of the vortex interacts with the main flow and a stagnant zone $C$ forms (Fig. 3).

It should be noted that when the $R e \geq 1750$ number is reached, pulsations of the vortex zone occur with respect to the longitudinal and transverse axis of the channel and the return flow along the bottom of the channel. This situation affects the redistribution of the stress-strain state in the flow.

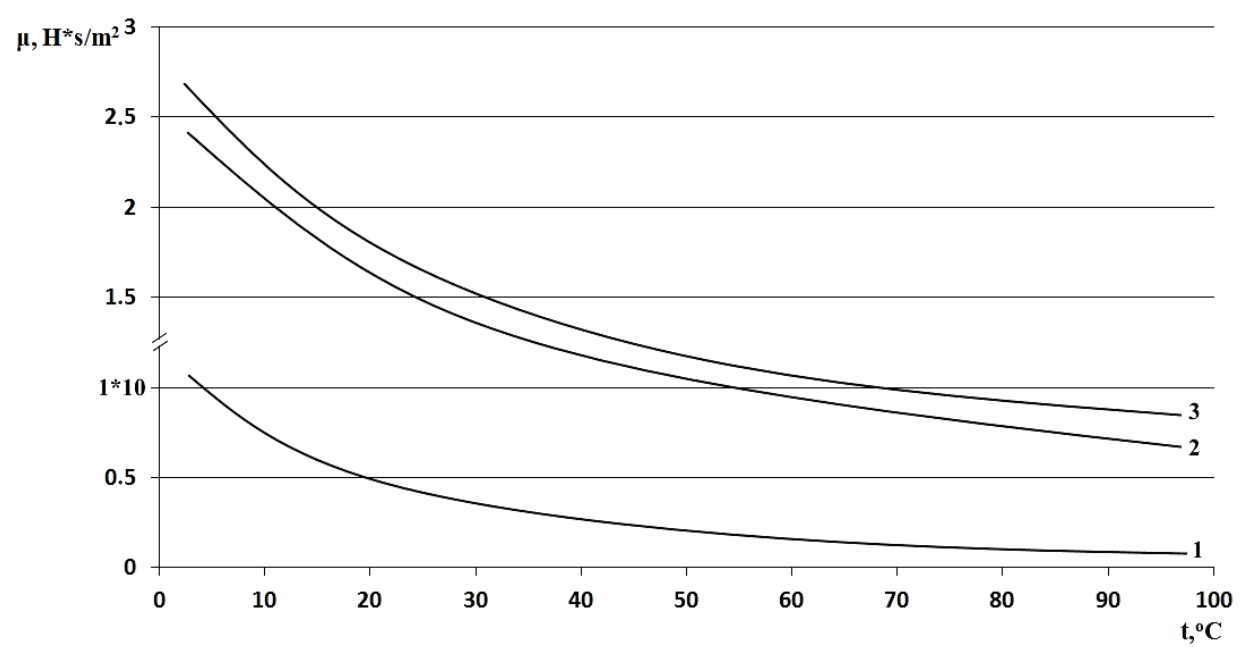

Fig. 2. Dependence of viscosity on temperature: $1-3 \%$ CMC; $2-8 \%$ CMC; $3-10 \%$ PVA

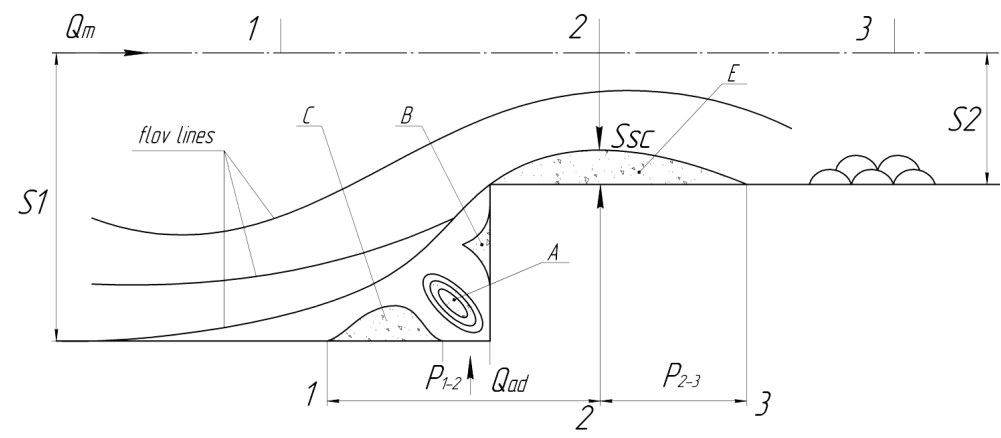

Fig. 3. Model of flow in the region of sudden narrowing of the flat-slot channel: $A$ - main vortex; $B, C-$ stagnant zones; $E$ - annular insulated cavity 
Thus, the above results allow to conclude that the dimensions of the vortex structures $A, B$, and $C$, as well as the process of their development, depend on the geometrical parameters of the local resistance, the rheological properties of the moving fluid, and the Reynolds number.

It should be noted that in the channel with a smaller cross-sectional area $\left(S_{2}\right)$, an annular isolated cavity $E$ is observed (Fig. 2). In this zone of secondary flows $\left(S_{c s}\right)$ tangential stresses on the channel wall have the same directions with the flow in the flow core, and the velocity gradient along the normal is insignificant. At the value $R e=1250$ in zone $E$ two vortex zones interacting with each other and having an $S$-shape are observed.

The energy loss for the investigated channel section can be represented as two components:

$$
n P_{1} \text { and } n P_{2} \text {, }
$$

where $n P_{1}=n P_{1-2}-$ reversible energy losses, determined on the section between sections $1-2$ (Fig. 3), and $n P_{2}=n P_{2-3}-$ irreversible energy losses, determined by the corresponding in the section $2-3$.

The total pressure loss in a given section of the channel, i. e., $n P=n P_{1-2}+n P_{2-3}$ is determined from the following expression:

$$
n P=\rho \frac{Q}{2 S_{2}}\left[\left(\frac{1}{K_{0}^{2}}-1\right)\left(\frac{1}{K_{c}}-1\right)^{2}\right],
$$

where $\rho$ - density of the liquid; $Q$ - flow rate; $S_{c s}$ - area of the compressed section;

$$
K_{0}=\left(S_{1} / S_{2}\right)>1, K_{0}=\left(S_{c s} / S_{2}\right)<1 .
$$

In the first approximation, the relationship between the coefficients $K_{0}$ and $K_{c}$ can be represented as:

$$
K_{0}=2 K_{c}-1 .
$$

As shown by experimental studies, there is a relationship between the coefficients $K_{0}$ and $K_{c}$, which can be represented as a graph in Fig. 4.

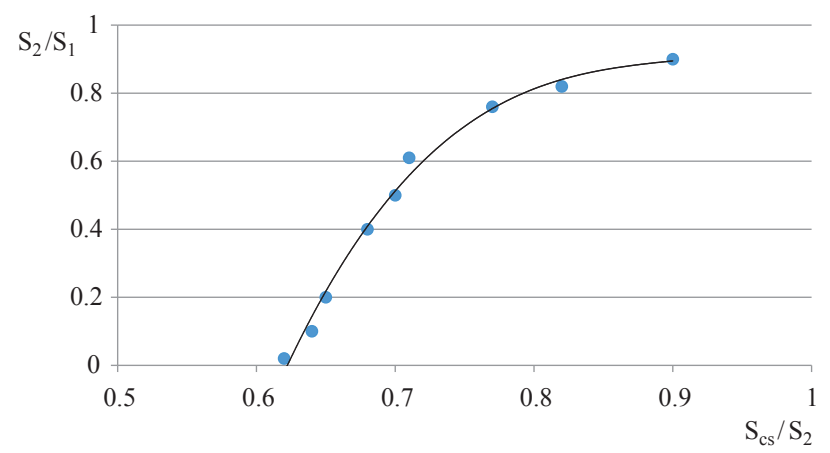

Fig. 4. Dependence of $S_{2} / S_{1}$ on $S_{c S} / S_{2}$ at flow of $3 \%$ CMC solution (carboxymethylcellulose) in sudden narrowing of the channel

Analysis of the experimental data shows that for the $3 \%$ aqueous CMC solution (flow index $n=0.967$ ), the error of formula (4) does not exceed $14 \%$. In the case where the fluid exhibits anomalies of viscosity to a greater extent, expression (4) needs to be corrected.
The dependence (4) can be represented in the following form:

$$
R e=\frac{\frac{n P \cdot D r \cdot s_{2}}{\mu \cdot Q}}{\left(\frac{1}{K_{0}^{2}}-1\right)-\left(\frac{1}{K_{c}}-1\right)^{2}},
$$

where $\mu$ - dynamic viscosity of the liquid; $D_{r}$ - reduced diameter.

The right-hand side of expression (6) contains a dimensionless quantity proportional to the energy loss in the region of sudden constriction and characterizing the compression degree of the flow in the channel with a smaller cross-sectional area.

For a Newtonian fluid, this quantity is numerically equal to the Reynolds criterion, and for a non-Newtonian medium it is proportional to the criterion $R e$ with a coefficient of proportionality $K_{c}$.

Thus, by analogy with the definition of the physical meaning of the Reynolds number, it can be concluded that the parameter obtained above also characterizes the ratio of inertia forces in the flow of a moving medium to viscous friction forces, but only in the investigated region. Essentially, the resulting dimensionless parameter (6) is the Lagrange criterion corrected for the region of the compressed flow (Fig. 4).

Given that $n P$ is defined as a sum of $n P_{1}+P_{2}$, then to determine the energy loss in the region of sudden narrowing of the channel, a relationship must be valid:

$$
R e=\frac{L a_{i}}{\left(\frac{1}{K_{0}^{2}}-1\right)-\left(\frac{1}{K_{c}}-1\right)^{2}}-\frac{L a_{r}}{\left(\frac{1}{K_{0}^{2}}-1\right)-\left(\frac{1}{K_{c}}-1\right)^{2}},
$$

where $L a_{i}$ - the Lagrange criterion corresponding to irreversible energy losses; $L a_{r}$ - the Lagrange criterion corresponding to reversible energy losses.

It should be noted that one of the most effective ways to control the hydrodynamic flow characteristics in the area of sudden narrowing of the channel is to supply an additional liquid flow rate $Q_{\text {add }}$ in the radial direction with respect to the main flow (Fig. 3). At the same time, it is possible to significantly change the location and size of the vortex structures $A, B, C$.

Supple of $Q_{a d d}$ also leads to a redistribution of the energy of the flow in an isolated vortex cavity $E$ (Fig. 3 ), at which part of the cavity energy is transferred back to the main flow. At a ratio $Q_{a d} / Q_{m}=0.16-0.24$ in a rectangular channel, after a sudden narrowing $\left(S_{1} / S_{2}=2\right)$, the character of the piezometric line changes in such way that its extremum associated with the pressure in zone $E$ disappears.

At the ratio $Q_{a d} / Q_{m} \approx 0.3$, in the region of Reynolds numbers $\left(R e \geq 10^{3}\right)$, the vortex structures break down and the turbulence of the stream is intense along the length of the hydrodynamic initial section located behind the sudden narrowing of the channel.

It is established that the dependence (1) has a powerlaw character, which is confirmed by the coefficient of correlation 0.9956 .

When determining the dependence of the viscosity of CMC and PVA solutions on the shear rate, as can be seen from the obtained results (Fig. 1), it is natural to decrease the viscosity value with increasing shear rate 
and the manifestation of the thixotropy phenomenon [16]. This is due to the fact that the investigated structures during deformation with a constant shear rate are gradually destroyed and this leads to a decrease in the effective viscosity. It should be noted that when the deformation is removed, the structure of the medium is gradually restored. At the same time, an increase in the concentration of solutions quantitatively changes this phenomenon, that is, an increase in the area of the hysteresis loop, which is formed by the flow curves (Fig. 1).

Analysis of the flow curves with increasing temperature (Fig. 2) causes a decrease in the shear stress and viscosity of the solutions. Evaluation of these data opens the possibility for obtaining rational modes of mixing components in the channels of the forming head during extrusion.

The flow pattern in the region of sudden narrowing of the channel (Fig. 3) shows the mechanism of formation and development of vortex structures.

It should be noted that the flow visualization method used has weak points related to the inability to determine the stress-strain state of the medium flow. At the same time, this method provides quite accurate information about the evolution of vortex structures in the region of sudden narrowing of the channel.

In favor of this assertion is a qualitative coincidence of the processes of development of circulation flows obtained by numerical modeling of the flow of viscoelastic media in plane step-like symmetric channels [2-5]. The quantitative discrepancy between the results can be explained by the choice in the above works of the rheological model Oldroyd-B, which characterizes the elastic properties of the liquid (finite relaxation time).

It should be noted that for the Oldroyd-B and FENE-P models in flat channels with a step configuration with constriction coefficients of 8:1, 16:1 for different Weissenberg numbers, the effect of formation, development and disappearance of the vortex structures is also manifested. But this happens with other values of the elasticity of the medium [6-12].

Analyzing the way to break the vortex zones from the walls of the sudden constriction at the radial supply of the flow (Fig. 3), it is possible to state that the ratio $Q_{a d} / Q_{m} \approx 0.3$ provides a detached flow with a sharp change in the flow parameters, characterized by a turbulent displacement.

\section{SWOT analysis of research results}

Strengths. Among the strengths of this research, it is necessary to note the obtained results on the control of vortex structures in the channels of forming equipment, which made it possible to develop the design of a device for introducing components into extruded material and to reduce energy costs for the process. This conclusion is supported by the above-mentioned results of the analysis of scientific periodicals and patent information in which such data are not available. It is for this reason, in the practical conditions of operation of mixing equipment, it is difficult to select priority measures for improving the input devices of components in extruded material. Using the same data obtained with respect to the hydrodynamic control of vortex structures for flow turbulence allows to solve the problem of choosing rational technological modes of mixing components. Criteria for choosing this are, on the one hand, an extended range of practical applications and equipment performance, and on the other hand, minimizing the costs for the modernization process itself. The latter may be due to a reasoned choice of constructive solutions of extrusion dies by the criterion of «price-quality», or by the criterion of reliability.

Weaknesses. The weaknesses of this research are related to the fact that the proposed solutions are based on the assumption of isothermal flow of media in the channels of forming equipment. At the same time, it is well known that such assumption for real extrusion processes turns out to be incorrect. The reason for this is the temperature factor affecting the process, for example, the temperature dependence of the viscosity of the components, the formation of a radial temperature inhomogeneity of the medium in the region of stagnant flow zones, and a number of other negative effects. As a result, research data used in the design of equipment can lead to a drop in performance and, in some cases, deterioration in product quality. Therefore, in order to prevent this weakness associated with the complexity of carrying out the non-isothermal experiment, special attention should be paid to the results of mathematical simulation of extrusion mixing processes. In other words, the experimental results supplement the information corresponding to the practical requirements for the design of extrusion dies despite the fact that the priority direction of equipment modernization is simple mathematical methods.

Opportunities. The opportunities lie in the following possible external factors. The technological considered object can be operated in Ukraine and the former Soviet republics. All objects with such functional purpose can today be considered physically as well as technologically obsolete. This circumstance can be considered stimulating in the sense that a developed device can be chosen among the list of mixing equipment, which will allow, taking into account the research results, to ensure acceptable quality of the mixing processes of the components. It is in this way that the task of eliminating the factor of moral depreciation can be solved in the conditions of concrete production. At the same time, the results obtained as a result of the implementation can become the basis for further development of the described research. In particular, the influence of the elastic-viscous properties of the mixing components on the technological process can be studied. This will allow to make appropriate changes in the methodology of calculation and design of equipment.

Threats. The difficulty in implementation of the research results is related to two main factors.

The first of these is the management of companies operating the equipment. The investment of additional funds in the acquisition of necessary equipment and the absence of a previously guaranteed high result is a deterrent for company management. The improperly chosen design of the extrusion die, designed to mix technological components, without taking into account the factors specific to the given operating conditions, can't at all provide a predictable result. This risk has all the grounds, since the results described in the work are obtained for the isothermal process of flow of anomalous viscosity media in the channels of the forming equipment.

The second factor is the market of modern extrusion equipment offered from world leading companies, oversaturated and assumes considerable competition. 
Thus, SWOT analysis of research results allows to identify the main directions for the successful achievement of the research objective. Among them: the development of mathematical methods for modeling non-isothermal flow of anomalous-viscous media in the channels of mixing equipment.

\section{Conclusions}

1. The influence of the rheological properties of the liquid on the processes of the vortex formation of the flow in the region of sudden narrowing of the channel is established. It is shown that manifestations of the anomaly of the viscosity of media significantly affect the value of thixotropic bonds, as well as the processes of the formation and development of vortex structures. With a decrease in the flow index in the power-law rheological equation from 0.967 to 0.652 , the dimensions of the main vortex A decrease by $38-40 \%$. The definition of a more precise relationship is difficult, since it is necessary to conduct additional expensive studies.

2. It is shown that for a ratio $Q_{a d} / Q_{m}=0.16-0.24$ in a rectangular channel after a sudden narrowing $\left(S_{1} / S_{2}=2\right)$, the character of the piezometric line changes in such way that its extremum associated with the pressure in zone $E$ disappears.

It is established that at a ratio $Q_{a d} / Q_{m} \approx 0.3$ in the region of Reynolds numbers $\left(R e \geq 10^{3}\right)$, the vortex structures are disrupted and the turbulence is intense along the length of the hydrodynamic initial section located behind the sudden narrowing of the channel. This indicates the possibility of practical use of this method of controlling vortex structures in the channels of extrusion dies of extrusion equipment. At the same time, obtaining a more accurate result is not guaranteed because of the inaccuracy of the measuring instruments used in the experiment.

3. It is established that the results of the studies indicate the possibility of practical use of this method of controlling vortex structures in the channels of the extrusion dies of extrusion equipment. Proof of this can be considered the developed device for the introduction of technological components in extruded material, protected by the patent of Ukraine No. 201503942 [18].

\section{References}

1. Torner R. V. Teoreticheskie osnovy pererabotki polimerov. Moscow: Khimiya, 1977. 462 p.

2. Bezvikhrevoe techenie vyazkouprugoy zhidkosti vo vkhodnom kanale ekstruzionnoy golovki / Kutuzov A. G. et al. // Vestnik Kazanskogo tekhnologicheskogo universiteta. 2012. Vol. 15, No. 21. P. 137-139.

3. Clemeur N., Rutgers R. P. G., Debbaut B. Numerical simulation of abrupt contraction flows using the Double Convected Pom-Pom model // Journal of Non-Newtonian Fluid Mechanics. 2004. Vol. 117, No. 2-3. P. 193-209. doi:10.1016/ j.jnnfm.2004.02.001

4. Boger D. V., Hur D. U., Binnington R. J. Further observations of elastic effects in tubular entry flows // Journal of Non-Newtonian Fluid Mechanics. 1986. Vol. 20. P. 31-49. doi:10.1016/0377-0257(86)80014-3
5. Verbeeten W. M. H., Peters G. W. M., Baaijens F. P. T. Differential constitutive equations for polymer melts: The extended Pom-Pom model // Journal of Rheology. 2001. Vol. 45, No. 4. P. 823-843. doi:10.1122/1.1380426

6. Three-dimensional velocity measurements in annular diffuser segments including the effects of upstream strut wakes Cherry E. M. et al. // International Journal of Heat and Fluid Flow. 2010. Vol. 31, No. 4. P. 569-575. doi:10.1016/ j.ijheatfluidflow.2010.02.029

7. Kutuzova E. R., Tazyukov F. Kh., Khalaf Kh. A. Dinamika techeniya vyazkouprugoy zhidkosti cherez ploskoe 8:1 suzhenie // Vestnik Kazanskogo tekhnologicheskogo universiteta. 2014. Vol. 17, No. 16. P. 83-85.

8. Mackley M., Rutgers R. P., Gilbert D. Surface instabilities during the extrusion of linear low density polyethylene // Journal of Non-Newtonian Fluid Mechanics. 1998. Vol. 76, No. 1-3. P. 281-297. doi:10.1016/s0377-0257(97)00122-5

9. Miller E., Rothstein J. P. Control of the sharkskin instability in the extrusion of polymer melts using induced temperature gradients // Rheologica Acta. 2004. Vol. 44, No. 2. P. 160-173. doi:10.1007/s00397-004-0393-4

10. Tazyukov F. Kh., Kutuzova E. R., Snegirev B. A. Potoki vyazkouprugikh zhidkostey modeley OLDROYD-B i FENE-P // Vestnik Kazanskogo tekhnologicheskogo universiteta. 2014. Vol. 17, No. 18. P. 120-122.

11. Tazyukov F. Kh., Khalaf H. A. Numerical simulation of the laminar flow of non-Newtonian fluid through a disk-type prosthetic heart value: proceedings // Diyala Journal of Engineering Sciences. 2010. P. 26-39.

12. Tatamikov A. A., Burtelov L. V. Generalised mathematical model of the throughput of the pressure zone of an extruder // International Polymer Science and Technology. 2004. Vol. 31, No. 12. P. 72-75.

13. Arda D. R., Mackley M. R. The effect of die exit curvature, die surface roughness and a fluoropolymer additive on sharkskin extrusion instabilities in polyethylene processing // Journal of Non-Newtonian Fluid Mechanics. 2005. Vol. 126, No. 1. P. 47-61. doi:10.1016/j.jnnfm.2004.12.005

14. Nosko S. V., Shevchuk A. A. The structure of flow in the complex duct in a radial admission of escapages // EasternEuropean Journal of Enterprise Technologies. 2013. Vol. 2, No. 7 (62). P. 57-60. URL: http://journals.uran.ua/eejet/ article/view/12390

15. Nosko S. V., Mossiychuk V. A. Issledovanie kinematicheskikh kharakteristik potoka v kanalakh litnikovoy sistemy metodami vizualizatsii // Vestnik NTUU «KPI». Mashinostroenie. 2011 Vol. 62. P. 79-82.

16. Tager A. A., Botvinnik G. O., Dreval V. E. Energiya i entropiya aktivatsii vyazkogo techeniya kontsentrirovannykh rastvorov polimerov. Moscow: Khimiya, 1970. 296 p.

17. Mikaeli V. Ekstruzionnye golovki dlya plastmass i reziny. Konstruktsii i tekhnicheskie raschety. Saint Petersburg: Profesiya, 2007. 472 p.

18. Formuiuchyi prystrii dlia vvodu tekhnolohichnykh komponentiv v yekstrudovanyi material: Patent No. 102591 UA, MPK V29S47 / Nosko S. V., Shevchuk A. A. Appl. No. 201503942. Filed: 24.04.2015. Published: 10.11.2015. Bull. No. 21, 3 p.

Nosko Sergey, PhD, Associate Professor, Department of Fluid Mechanics and Mechatronics, National Technical University of Ukraine «Igor Sikorsky Kyiv Polytechnic Institute», Ukraine, e-mail: noskosv@ukr.net, ORCID: https://orcid.org/0000-0001-8631-6118

Ahaiev Ihor, Department of Fluid Mechanics and Mechatronics, National Technical University of Ukraine «Igor Sikorsky Kyiv Polytechnic Institute», Ukraine, e-mail: agaev2395@gmail.com, ORCID https://orcid.org/0000-0003-2776-7140 